\title{
Advances in the Octopus maya digestive physiology
}

Avances en la fisiología digestiva de Octopus maya

Rosario Martínez-Yáñez*, Carlos Rosas**

\begin{abstract}
Red octopus (Octopus maya) is an important fishery resource in Mexico, due to its high commercial value and domestic and foreign demand. An alternative to fishing is the mariculture. Cephalopods digestion is a two-part process: extracellular and intracellular. This paper describes the progress made in Octopus maya digestive physiology study, particularly, in the digestion temporality, absorption and assimilation of crab in an attempt to assess the nutrients dynamic and usage along the digestive tract and, how these are transported, stored and used as an energy source for growth.
\end{abstract}

\section{RESUMEN}

El pulpo rojo (Octopus maya) es un importante recurso pesquero en México, debido a su alto valor comercial y demanda interna y externa. Una alternativa a la pesca es la maricultura. La digestión de los cefalópodos es un proceso de dos partes: extracelular e intracelular. El presente trabajo describe los progresos realizados en el estudio de la fisiología digestiva de Octopus maya, en particular la temporalidad de la digestión, la absorción y asimilación de carne de cangrejo, en un intento por evaluar la dinámica de nutrientes y el paso a lo largo del tracto digestivo y, cómo éstos son transportados, almacenados y utilizados como fuente de energía para el crecimiento.

\section{INTRODUCTION}

Red octopus (Octopus maya) is an important fishery resource in Mexico. Therefore, it confronts a great catch strain and in recent years has showed an inconsistent production. An alternative to fishing is the mariculture. This species has great advantages for cultivation. However, reliance on natural diets and the lack of a specific and economical feed have slowed the production development of this and other cephalopods at commercial scale round the world. There is a consensus that several crustaceans are the most common diet for octopus species, in both juveniles (Aguado-Giménez \& García-García, 2002; Boucaud-Camou \& Boucher-Rodoni, 1983; Pérez, López, Águila \& González, 2006; Prato, Portacci \& Biandolino, 2010; Rosas et al., 2013; Zuñiga, Olivares \& Ossandón, 1995) and paralarvae (Roura, González, Redd \& Guerra, 2012; Uriarte et al., 2010). Cerezo-Valverde et al. (2013) studied 33 marine species and their nutrition, and concluded that arginine and leucine were the limiting amino acids in most of the samples analysed, suggesting that the inclusion of those amino acids in diets comprised of crustacean meals could improve fish or animal meal in diets for Octopus maya. It is interesting to note that arginine (Arg), along with other amino acids (aa), is one of the most abundant in the free amino acid pool in the crab Callinectes sapidus; these are widely distributed in the muscle and haemolymph because of their role as osmotic effectors in this and other euryhaline crustacean species (Lynch \& Webb, 1973). As Arg and other amino acids

\footnotetext{
* Departamento de Agronomía, División de Ciencias de la Vida, Campus Irapuato-Salamanca, Universidad de Guanajuato. Ex-Hacienda El Copal, carretera Irapuato-Silao km 9, Irapuato, Guanajuato, México, C.P. 36500. Tel.: (462) 6241889. E-mail: ar.martinez@ugto.mx

** Unidad Multidisciplinaria de Docencia e Investigación, Facultad de Ciencias, Campus Sisal, Universidad Nacional Autónoma de México (UNAM). Puerto de Abrigo s/n, Sisal, Hunucma,Yucatán, México, C.P. 97356. Tel.: (988) 931-1000. E-mail: crv@ciencias.unam.mx
} 
play an important role in octopus nutrition, its ingestion may act to accelerate the uptake of other nutrients in the octopus digestive gland, as has been described in terrestrial animals (Herzberg \& Lerner, 1973).

Cephalopods digestion is a two-part process: extracellular and intracellular. Extracellular takes place along the digestive tract, which begins in the mouth, follows the anterior stomach (crop), the posterior stomach, cecum and ending with the digestive gland (DG) where the chyme is absorbed. Intracellular develops inside the DG where nutrients hydrolyzed to make them bioavailable. Therefore, this organ plays an important role in this process (Boucher-Rodoni, 1976; BoucherRodoni, Boucaud-Camou \& Mangold, 1987; Budelmann, Schipp \& Boletzky, 1997). To date, studies on Octopus maya digestive physiology were not been carried out in depth. Develop a diet is a fundamental requirement to understand cephalopods digestive physiology, especially octopuses. This will allow designing experimental diets according to the species in order to achieve a highly digestible diet and suitable for cultivation that promotes growth. Using Octopus maya as a model, the obtained results allow general schedules of digestive physiology. These could become a proposal to apply for other tropical species, being an important contribution towards the development and management of a balanced feed.

\section{Digestive Gland}

Digestive Gland (DG) has a fundamental role in the cephalopods digestive process, provides digestive enzymes and stores nutrients (Bustamante, 1998). Especially, those that are used as a metabolic energy source (Hatfield, Rodhouse \& Barber, 1992). Glucose is the main cells energy source and it is stored as glycogen (Murray et al., 2013) in the digestive gland. O. maya DG is represented by a single cell type, organized as acini: the digestive cell. The maturation process of this organ is characterized by the gradual disappearance of yolk platelets in contrast to the gradual appearance of heterophagosomes, heterolysosomes and residual bodies within the cells; at the same time, complete and mature digestive cells develop gradually evolving the same columnar structure and function of a acinar- tubule organ (Martinez et al., 2011a). Similar to what was observed in S. officinalis, the consumed food affects the digestive cells kinetics that forms the O. maya DG, which are affected by the presence of food and change during digestion (Boucaud-Camou, 1968; Boucaud-Camou, 1973; Perrin, 2004; Perrin, Le Bihan \& Koueta, 2004).
In Octopus maya, digestive cells work asynchronous responding to the food presence in the digestive tract. During this process, the digestive cell varies according to the role played depending on the time in the postprandial period, either as an enzymes synthesizing cell or receiving the produced chyme for absorption and assimilation (Martínez et al., 2011a). Similar to other cephalopods species, Octopus maya DG performs intracellular digestion and release enzymes to carry out extracellular digestion (Boucaud-Camou \& Boucher-Rodoni, 1983; Martínez et al., 2011a; Martinez et al., 2011b). Consumed food affects the digestive cells kinetics that forms the Octopus maya DG. Which are, at the same time, affected by the food presence and change during the digestive process. Digestive cells work asynchronous responding to the food presence in the digestive tract. During this process, the digestive cell varies according to the role played depending on the time in the postprandial period, either as an enzymes synthesizing cell or receiving the produced chyme for absorption and assimilation. Many studies have discussed the utility of the digestive gland of Octopus maya and other cephalopods as a tool for monitoring the nutritional condition of animals fed different types of food (Águila y Elvira, 2007; Cerezo-Valverde et al., 2013; Estefanell et al., 2013). To date, we found that the type of diet strongly influenced biochemical characteristics in the DG of Octopus maya. Águila y Elvira (2007), fed octopuses with a diet made out of fishmeal and fish hydrolysed protein, and found that the energy content and total lipid values were lower than in crabmeat fed animals. In that study, they also found that there was an inverse relationship between soluble protein and DG glycogen in animals fed crab, suggesting that DG glycogen is the result of a gluconeogenic pathway. As consequence, crab fed octopuses observed higher levels of hemolymph glucose in comparison with octopuses fed elaborate diets. Those results and other experiments performed using Octopus maya (Baesa-Rojano et al., 2012; Martinez et al., 2011 b; Rosas et al., 2011) confirmed that fed crab animals used ingested protein as a source of energy via a gluconeogenic pathway, facilitating the accumulation of glycogen and its posterior release as glucose. DG protein and glycogen of $O$. maya followed an inverse relationship along the digestive process, confirming the role of protein as a source of energy during that process. These results suggest that glycogen accumulation must occur between meals, once the DG's glycogen level has returned to normal and nutrients are newly available for the next meal. 


\section{Digestive Enzymes}

Morishita (1972) observed first the role of acidic proteases during digestion in octopus, when reported acidic enzymes in the crop, stomach and DG of $O$. vulgaris. In O. maya, the characterization of DG proteases shows that these enzymes are essentially acidic (Martinez et al., 2011b), similar to those reported in squid and cuttlefish (Cárdenas-López \& Haard, 2005; 2009; Perrin et al., 2004). Gastric juice (GJ) enzymes are exopeptidases from the cathepsin family which requires an acidic environment to develop their maximum activity, thus, lyophilization allows the protein structure used to be bioavailable (native state) so these enzymes can break the amino acids bonds (Martinez et al., 2014), opposite if the raw materials were dried by heat. The significance of the partial enzymatic characterization by means of $\mathrm{pH}$ is that extracellular digestive enzymes are the first to be in contact with food. The $\mathrm{pH}$ at which a diet is prepared affects the digestive environment; therefore, it affects directly the digestive enzymes activity. The maximum activity of the Octopus maya DG and GJ enzymes occur at different $\mathrm{pH}$, with optimum values of 3 to 4 and 6 , respectively, suggesting that the intracellular and extracellular enzymes are different and Octopus maya DG proteases show maximum activity at acidic $\mathrm{pH}$, indicating the presence of lysosomal enzymes associated with chyme intracellular digestion. $72 \%$ of the observed inhibition when using an aspartic proteases inhibitor suggested cathepsin D presence in the DG, while in the crop $18 \%$ of the observed inhibition in crop's GJ suggests that these enzymes are released with the cell portions in the apocrine secretion process that happens in the DG and reaches the crop (Martinez et al., 2011b).

Other enzymes working in acid environments are also part of the GJ, suggesting that perhaps other cathepsins are present in the DG apocrine secretions conducting extracellular digestion. Recent studies have shown that cathepsin L is present in the squid's DG (Cárdenas-López \& Haard, 2009) suggesting that this and other cathepsins may also be present in the $O$. maya GJ. O. maya observed a digestive acidic environment in both in the GJ and the DG (Martinez et al., 2011a). Identified aspartic acid proteinases (cathepsin D) were in both sites as well (Martinez et al., 2011b). Although cathepsins have been identified as digestive intracellular enzymes in invertebrates (Mukhin, Smirnova \& Novikov, 2007), that acidic proteases were activated in the GJ during the extracellular digestion of the meal in both species. During the process, the
$\mathrm{pH}$ of $O$. maya fluctuated between 5 and 6 , favouring the activity of aspartate proteases (like cathepsin D), which along with a weakly alkaline activity, completed the digestion of complex ingested nutrients (i.e. myofibrillar protein) (Martinez et al., 2011a; 2011b). The GJ enzyme activity of $O$. maya had several peaks throughout the digestive process, indicating that the release of digestive enzymes from the DG occurred in two pulses (20 min - $60 \mathrm{~min}$ and $100 \mathrm{~min}-180 \mathrm{~min}$ ) (Martinez et al., 2011b; Semmens, 2002).

\section{Digestive Process: Morphometric and Biochemistry}

The digestive process in O. maya involves two large steps: a first characterised by soluble nutrients passing rapidly along the digestive tract, which were absorbed and used for muscle protein synthesis; and a second slower step where complex nutrients were digested and transformed into useful molecules that were transported to the muscle or stored temporarily in the DG. At the date, there is a successful diet for Octopus maya growth (Martínez et al., 2014). This diet was designed using morpho-physiological data derived of the studies showed in the actual paper. When a new species must be cultured, this type of studies are highly recommended before test any diet, because with this type of information the probability of design a diet according with physiological functioning of animals will be higher. The digestion process starts when the digestive tract is ready to receive a meal. From the results obtained by Martínez et al. (2011a; 2011b; 2012) a conceptual model in which the most important aspects of the Octopus maya digestive physiology has been developed (figure 1). A summary of the digestive process occurring in each section of the digestive tract of $O$. maya shown in table 1 . In this summary, the type of response observed (namely response) and its function as a part of the digestion and assimilation processes (namely function) is included in an attempt to explain the sequence of events that occur at the same time along the digestive tract during digestion.

Octopus maya prepare its digestive tract for digestion. Before ingestion, digestive enzymes and zymogens in GJ were located in the crop, stomach, caecum and digestive gland. At the same time, protein, fatty acids and cholesterol in the haemolymph were considered a baseline and interpreted as nutrients required to maintain the fasting octopus 
period (Rosas et al., 2011) (table 1). In this sense, García-Garrido, Hachero-Cruzado, Domingues, López $\&$ Rosas (2011) showed that a fasting time of 3 days is enough in O. vulgaris to provoke mobilisation of lipids, Chol, AG, total protein and amino acids of octopus mantle to be use as a source of energy. In O. maya, mobilisation of nutrients occurred in animals undergoing $24 \mathrm{~h}$ fasting, suggesting that octopus species are well adapted to tolerate short fasting periods. In fact, George-Zamora, Viana, Rodríguez, Espinoza \& Rosas (2011) showed that a period of 10 days of fasting is totally reversible in Octopus maya; in that study was observed that amino acids were used to sustain the energy metabolism of animals. Inside Octopus maya digestive cell under fasting conditions, none or few heterolysosomes, secretory lysosomes, residual bodies and heterophagosomes were observed. Showing that cells are passive, as there is no food in the gastrointestinal tract that stimulates synthesis and release of enzymes (secretory lysosomes). Verified by observing the acid and alkaline proteases activity in the GJ from the fasting DG, since these enzymes showed a lower activity compared to that observed at 60 and 120 min after feeding.

Once the crab was offer to the octopus, they immediately reacted to it. According to previous studies we considered that $O$. maya with a wet weight of around $900 \mathrm{~g}$ need $20 \mathrm{~min}$ to ingest a crab of around $100 \mathrm{~g}$ in wet weight (Martínez et al., 2011b). As was observed by Martinez et al. (2012), when crab caught, the octopus injects saliva and waits for the enzymes to open the crab. After, chyme containing partially digested crab flesh was ingested, the digestion process started. High concentrations of soluble protein recorded in chyme, suggesting that nutrients rapidly transported from the digestive tract to the DG, where digestion began. Chyme formed with the consumed and macerated food together with the salivary glands secretion (figure 1a). During the first and second hours after alimentary bolus is transport to the crop (anterior stomach) where the digestive environment under fasting conditions is acidic and the extracellular digestion takes place. The role of the salivary glands in the external digestion of cephalopods is recognise as a source of proteases and venoms (Boucaud-Camou \& Boucher-Rodoni, 1983; Undehim et al., 2010). Actual results indicate that, the first chyme pulses formed in the crab and in the digestive tract during the first minutes after the meal (mixing salivary enzymes and soluble protein from the crab) play a key role in activating the digestion of Octopus maya.

Digestive process involves two main steps: the first is characterised by soluble nutrients passing rapidly along the digestive tract, where they are absorbed and used for muscle protein synthesis, while the second is slower, and involves complex nutrients being digest and transform into useful molecules that are transport to the muscle or store temporarily in the DG. Due to the first digestion acidic environment, cathepsin $\mathrm{D}$ may be present. The GJ's pH observed in the cecum and GJ secreted by DG indicates that these organs are ready to receive the produced chyme. An acidic digestive environment is conducive to proteins hydrolysis, because the proteases type (lysosomal) cathepsins are release and are most active in low $\mathrm{pH}$.

The GJ's pH observed during the chyme formation through the digestive tract is between 5 and 6 . According to Boucaud-Camou \& Boucher-Rodoni (1983), octopus protein digestion starts when the posterior salivary glands excrete enzymes that initiate the external digestion of the prey. In O. maya, chymotrypsin activity in the posterior salivary glands is involved at the beginning of the external digestion, facilitating the digestion of soluble protein in the crab before its ingestion. Between $60 \mathrm{~min}-120 \mathrm{~min}$ of the postprandial period, the consumed food reaches the crop (figure 1a) presenting a $\mathrm{pH}$ increase up to 5.9. This $\mathrm{pH}$ change suggests that the crop digestion begins with the release of acidic extracellular enzymes (figure $1 \mathrm{~b}$ ). The high activity of GJ's proteases from the DG observed after feeding indicates that digestive enzymes are secrete into the DG lumen probably to be used during the chyme formation in the crop. To this point, it appears that some of the DG acini shown chyme in the lumen and $O$. maya digestive cell has few heterolysosomes inside, an increase occur in the secretory lysosomes production and the consequent release of them and their content (enzymes) to acinar lumen by apocrine secretion. The high density of secretory lysosomes in Octopus maya DG indicates that extracellular digestive enzymes were release after the first hour of consuming the food. Apparently, relationship between food and the secretory lysosomes production is a species-specific process and a sharp increase in the density of this type of lysosomes was observed 60 min post-feeding and remains constant through the digestive cycle.

Once the external digestion process initiated, soluble proteins forming the chyme pass from the mouth to the DG in a short time, peaking in the crop, stomach and caecum $40 \mathrm{~min}$ - $80 \mathrm{~min}$ after the meal. Although we do not know the exact mechanism of action of the soluble protein into the chyme, we can hypothesise that it has several key roles. One of them could be to activate zymogens of acidic and alkaline enzymes located in the crop and other sections of the digestive tract where zymogens were stored in preparation for the next meal. Besides polypeptides, it is highly probable that there are other enzymes in the chyme, both from the crab and from 
the salivary glands injected during ingestion of food (Boucaud-Camou \& Boucher-Rodoni, 1983). In fact, it is possible to hypothesise that there are enzymes in the chyme that can activate zymogens of enzymes located along the digestive tract, functioning as a signal to start the digestion of more complex nutrients, as has been described in general as the mechanism of activation of zymogens of this type of enzyme (Hedstrom, 2002). Zymogens in the digestive tract of cephalopods have been previously reported. Studying the cytological structure of the digestive gland during feeding of Sepioteuthis lessoniana, Semmens (2002) observed that digestive enzymes were released one hour after feeding, concluding that those enzymes were stored in the stomach as zymogens to increase digestive efficiency. Results obtained in the present study suggest that the role of chyme as an activator of zymogens and other digestive process can be extend at the absorption sites, for activation enzymes and in the mobilisation of reserves in the DG (table 1). With the first chyme pulse, soluble protein and amino acids can stimulate the brush wall of the octopus digestive gland cells, absorbing nutrients and activating endocytosis. Although we do not know how those mechanisms operate in the octopus, in terrestrial animals, it has been observed that some free amino acids can facilitate the absorption of other amino acids, depending on the metabolic relationship between them or whether some specific amino acids are pre-loaded in the intestine during in vitro assays (Herzberg \& Lerner, 1973). In O. maya, the first pulse of chyme could be the pre-loaded amino acids and other nutrients to facilitate, as in terrestrial animals, the absorption of the bulk of nutrients coming from the digestion of complex nutrients to be absorbed.

Octopus maya in fasting or postprandial period, the diameter of secretory lysosomes is constant, suggesting that not only the number but also the size of the latter are maintained through digestion. This implies that Octopus maya could be ready for continuous enzymes production in preparation for feeding. Once the chyme has been absorbed and entered into the DG cells, soluble protein can also stimulate zymogens of acidic intracellular enzymes located in the heterophagosomes of the DG (Martinez et al., 2011b), enabling the intracellular digestion of more complex nutrients. At the same time and with all of the system activated, heterophagosomes initiate the mobilisation of energetic molecules that permit the transportation of molecules to the haemolymph and finally to muscle tissue (table 1). Results obtained in Octopus maya provided evidence that this activating mechanism included the rapid mobilisation of nutrients, presumably directed at fuel for intracellular digestion. Reductions in DG glycogen along with an increase of DG soluble glucose was observed in Octopus maya, showing that once the digestion had been initiated, energetic reserves were used. Between $60 \mathrm{~min}$ and $120 \mathrm{~min}$ postprandial, glycogen concentration in Octopus maya DG decreases about 50\%, showing that energy reserves are mobilize for food capture and consumption.

At the beginning of the digestion process $(20$ min $80 \mathrm{~min}$ after feeding), soluble AG and Chol were also used as a source of energy in Octopus maya. This is the first time that those soluble nutrients have been identified to participate in digestion in O. maya. It is interesting to note that AG had one peak 180 min after the meal in Octopus maya, while Chol showed two peaks (one $80 \mathrm{~min}$ and the other $180 \mathrm{~min}$ after feeding). Those differences are in accordance with the form in which different nutrients were stored in prey. Acylglycerols in crustaceans are mainly stored in the DG and muscle of the crab (D'Abramo, 1997), from where octopus enzymes should extract it. Results obtained in the present study suggest that AG appears in the DG when more complex nutrients are digested, $180 \mathrm{~min}$ after the meal, because AG was extracted from crab tissues only until that time. In crustaceans, Chol is an essential nutrient that is stored in the DG, muscle and haemolymph, from where it is mobilised to be use as a precursor of moulting hormones or growth (Pascual, Gaxiola \& Rosas, 2003; Rosa, Costa \& Nunes, 2004; Rosas et al., 2007; Teshima, 1997). Those characteristics of Chol clearly explain why this molecule showed two peaks in Octopus maya DG, where it is evident that Chol was obtained from the meal on two occasions: from soluble nutrients in the first chyme pulse (probably soluble cholesterol found in haemolymph and other tissues) and after, when the more complex nutrients were digested. It is interesting to note that both nutrients were maintain in the DG, where they were presumably used as a source of energy, because neither of the nutrients was significantly released into the blood during the digestion process.

At this stage, there is a lack of information concerning phospholipids and its role in for example the repartition of circulating cholesterol in tissues (hemolymph). In fact, only haemolymph glucose levels changed significantly during the digestive process of $O$. maya, suggesting that those molecules were release to support the energy source in the muscle and other organs during that time. As in other invertebrates, glycogen in cephalopods is a precursor of metabolic intermediates in the production of energy and nonessential amino acids, as it is part of the muscle energy pathways (Rosa, Pereira \& Nunes, 2005b), and a source of energy for gonadal development (Rosa et al., 2004; Rosa, Costa, Bandarra \& Nunes, 2005a). 
Table 1.

Evolution of the digestive process, absorption and assimilation in wild pre-adults of O. maya.

min.

Location

\section{n}

Gastric juice (GJ) present in the crop, stomach and

Digestive caecum with low enzymatic activity. Also, low enzymatic tract activity in the DG. High levels of soluble protein, Acyl glycerides (AG) and cholesterol; low levels of glucose in the DG.

0

Plasma levels of soluble protein. Relatively low levels of AG, glucose, cholesterol and AA.

Muscle Low levels of soluble protein and glycogen.

\section{\begin{tabular}{l|l}
$\begin{array}{l}\text { External } \\
\text { digestion }\end{array}$ & $\begin{array}{c}\text { Chymotrypsin and other alkaline enzymes from posterior } \\
\text { salivary glands acting on the flesh of crabs (Morishita }\end{array}$ \\
\hline
\end{tabular}} $0-20$ 1972; Águila y Elvira, 2007).

Peaks of chime volume along digestive tract along with Digestive peaks of soluble protein, enzyme activity in the GJ and DG tract along with protein, glucose and cholesterol. Reduction in AG and Cholesterol.

\section{$20-80$ \\ Plasma Plasma protein reduction. Peak of glucose. Margina increments of AG and cholesterol. Peak of AAs. \\ Muscle Peak of soluble protein. Glycogen levels remain low and almost constant during this period.}

Second peaks of chime in the crop and stomach. Strong reduction of chime volume in the caecum. Second

Digestive peaks of soluble protein in chime and enzyme activity tract in the GJ and DG. Peak of glycogen and progressive increment of soluble protein and glucose. Peaks of AG and cholesterol.

\section{Protein, cholesterol and AG are maintained constant \\ Plasma during this period. A peak of glucose was registered. A second peak of AAs was registered. \\ $80-180$ Peak of soluble proteins was registered. Glycogen} remained almost constant.

Reduction of chime volume in the crop while an increment of volume is registered in the stomach and caecum. Reduction of soluble protein along the digestive tract. Digestive Reduction of acid and alkaline enzyme activity in the crop tract and stomach was observed. Peaks of acid and alkaline enzyme activity in the caecum and DG were observed.
Starts chime formation into the crab. External digestion promoting formation of soluble nutrients (BoucaudCamou and Boucher-Rodoni 1983).

Once the chime arrives in the digestive tract, soluble nutrients are digested and absorbed into the DG. Presumably glycogen and AG of the DG are used as a fuel for this first digestion. Glucose, coming from glycogen degradation is presumably sent more quickly to the haemolymph to be used as a fuel for protein synthesis in muscle.

Chime is progressively digested in the crop and stomach. A second pulse of enzymes from the DG is sustaining external digestion of more complex ingested nutrients. Gluconeogenesis is activated and lipids accumulating in the DG are sent to the plasma where they are maintained constant. AAs from digestion are sent to the haemolymph to be distributed and used presumably for protein muscle synthesis.

\section{Progressive increment of soluble protein while glucose, AG, cholesterol and glycogen remained constant. \\ Plasma \\ Reduction in protein, AAs and glucose levels. AG and cholesterol remain constant. \\ Muscle Reduction in soluble protein and peak of glycogen concentration.}

$180-360$

Stomach reaches its maximum chime volume while a reduction in chime volume of the caecum is observed.

Digestive Soluble protein along the digestive tract is reduced tract along with enzyme activity in the GJ and DG. Proteins reach their maximum level in the DG while glucose, AG, cholesterol and glycogen remain constant.

480
External digestion is located mainly in the caecum where a new pulse of enzymes coming from the DG sustains that activity. Soluble proteins accumulate in the DG presumably to be used as new digestive enzymes and for glycogen synthesis. The DG passes nutrients to the haemolymph to be transported to tissues. Lipids are apparently more slowly digested than proteins. Nutrients are stored in muscle; proteins are used for glycogen synthesis.

$$
\begin{array}{c|c}
\text { Increment of proteins reaching values similar } \\
\text { Plasma } & \begin{array}{c}
\text { to those observed before feeding. AG and cholesterol } \\
\text { remained constant, while low values of AAs and glucose } \\
\text { were registered. }
\end{array} \\
\text { Muscle } & \begin{array}{c}
\text { Low values of soluble protein and glycogen were } \\
\text { registered, similar to those observed before feeding. }
\end{array}
\end{array}
$$

At the end of digestion, a pulse of GJ is launched presumably to be sent to the crop for the next meal. That pulse helps to end the external digestion in the caecum. Synthesis of new enzymes starts in the DG where soluble proteins are stored. Internal digestion of the last nutrients occurs in the DG where lipids appear as the most difficult nutrients to digest. End of the digestion, absorption and assimilation processes.

Source: Linares et al. (2015). 


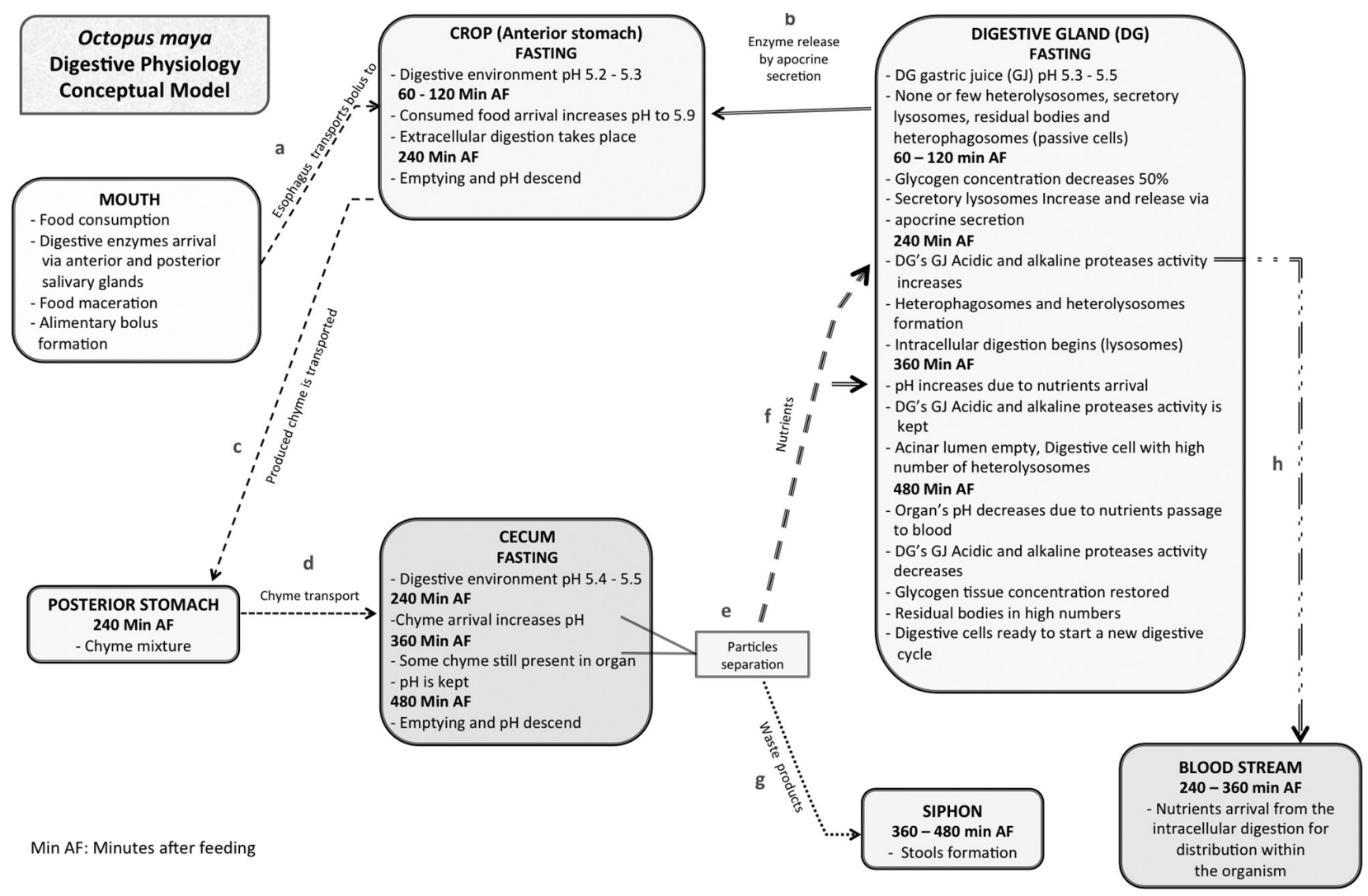

Figure 1. Octopus maya digestive physiology. Conceptual model. Source: Author's own elaboration.

Following the chyme pulses, essential amino acids and non-essential amino acids showed two peaks in Octopus maya haemolymph, indicating that there was amino acids flow during the first chyme pulse (40 min after meal) and another during the peak digestion of complex proteins (140 min - 180 min after meal). According to our records, this is the first time that such AA variations during the digestion process have been shown in cephalopods. The results suggest that, at least using crab as a diet, all of the amino acids passed to haemolymph to be mobilised in other tissues. Previous studies performed in Octopus maya demonstrated that Phe, Ile, Ala, Glu, and Ser are use as metabolic fuel, while His, Arg and Lys are accumulate during starvation (George-Zamora et al., 2011). In this sense, and according to the present results, we can hypothesise that AA peaks were, at least in part, mobilise to be use for growth and for glycogen synthesis in the muscle. Peaks of soluble protein observed at the same time as AA peaks support that finding. When studying 14 cephalopod species it was demonstrated that
AA, and in particular Pro and Arg, are the basis of the energy metabolism of pelagic, nektobenthonic, benthic and benthopelagic cephalopods (Rosa et al., 2005b).

Cephalopod muscle biochemistry includes complex mechanisms for the use of protein as a source of energy and, at the same time, an accumulation of biomass. Muscle growth in cephalopods involves two processes: i) hyperplasia, the generation of new muscle fibres; and it) hypertrophy, the increase in size of those fibres that are already in existence (Semmens, Doubleday, Hoyle \& Pecl, 2011). In their study, Semmens et al. (2011), observed the hyperplasia process in $O$. pallidus through the histological analysis of mantle muscle fibres. Poor and rich mitochondrial muscle fibres were observe even in octopus adults, demonstrating a mechanism by which octopus species maintain non-asymptotic growth during their life cycle. Although hyperplasia has not yet been demonstrated in Octopus maya, we can assume that a similar growth process occurs in those species and that those processes have a high demand for nutrients and energy for protein 
synthesis. In cephalopods, as in other invertebrates, glycogen is mainly derived from dietary proteins, via amino acid metabolism (Miliou, Fintikaki, Kountouris \& Verriopoulos, 2005; Rosas et al., 2002). In the present study, we observed that glycogen peaks follow a peak of soluble protein, suggesting that those proteins were first synthesised from AA coming from haemolymph to be use later as a source of energy via the gluconeogenesis pathway.

At 240 min of the postprandial period, chyme slowly reaches the cecum from the crop and subsequent stomach (figure 1c and 1d), crop's pH returns to its initial acidic environment, possibly preparing for the next digestion or an adjustment is made releasing new enzymes to maintain the acidic environment during transit of chyme through the digestive tract. Observing $\mathrm{pH}$ changes during the digestion process, it is evident that when the chyme reaches the cecum a $\mathrm{pH}$ change in the environment occurs from 5.4 to 5.9 , suggesting again the effects of digestion in the environment of the gastrointestinal tract. Considering $\mathrm{pH}$ data, a regulatory mechanism could be operating to keep the digestive environment around 6, the right level where GJ's enzymes have their maximum activity observed. To maintain the acidic environment and at the same time the activity of the acidic enzymes Octopus maya may release more GJ during the digestion process to keep the maximum activity of these enzymes, which are more active than alkaline digestive enzymes.

Between 240 min and 360 min postprandial period chyme from the cecum reaches the DG (figure 1c) and a separation of particles is performed (figure 1e), nutrients reach the DG (figure 1f) and now heterophagosomes are formed apically and heterolysosomes in the middle part of the digestive cell, decreasing the secretory lysosomes density. This indicates that the extracellular digestion phase is completed and intracellular digestion and chyme absorption from the cecum carried out. Stools formation starts from 360 min postprandial (figure 1g). DG Intracellular digestion is carry out by lysosomes, which essentially contain acidic enzymes in its interior. Interestingly, the maximum alkaline digestive enzymes activity at 240 min postprandial were only observed in cultured octopuses, suggesting that these youth may show a faster metabolism than wild pre adults, suggesting that the size (wet weight) and age could affect the food transit in the cephalopods digestive tract.

The DG's GJ maximum activity observed $360 \mathrm{~min}$ after feeding indicating the arrival of chyme to DG from the cecum (figures 1f). The digestive cell is re- plete with heterolysosomes, reducing the heterophagosomes and begins forming residual bodies, while continuing the nutrients passage within the blood for distribution (figure $1 \mathrm{~h}$ ). This step took at least $120 \mathrm{~min}$, during which the cecum still maintaining a relatively high $\mathrm{pH}$. Interestingly, the maximum protease activity observed $6 \mathrm{~h}$ after feeding indicating that enzymes present in the chyme are still active when they reach the DG lumen. In Octopus maya, 480 min post-feeding a $\mathrm{pH}$ reduction suggests that the DG activity gradually reduced along with the enzymatic activity reduction in the DG lumen. At this time, a new release of digestive enzymes could be responsible for the low $\mathrm{pH}$ observed in the crop and DG in preparation for a new digestive cycle, suggesting that a reserve of active extracellular enzymes and an appropriate digestive environment $\mathrm{pH}$ being kept. At 360 min, postprandial DG acinar lumen observed empty. The absorption and nutrients passage from the digestive tract into the blood for distribution within the rest of the body indicated that the intracellular digestion is completed (figure $1 \mathrm{~h}$ ).

As expected, the residual bodies are absent in the digestive cell during fasting and growing as digestion takes place. A peak in the residual bodies density was observed in animals 360 min after feeding, indicating that the rests removal process has reached its maximum level. At 480 min postprandial period, a decrease in the DG acid and alkaline proteases activity were observed along with a very low residual bodies density stating that the digestive cycle has ended. Once intracellular digestion completed at $480 \mathrm{~min}$ postprandial, digestive cells are ready to start a new digestive cycle. Is observed a heterolysosomes reduction inside the digestive cell, thus, these stocks can be used for the glucose production. Considering that the cephalopods metabolism is essentially protein based, it is logical that the glycogen stored in the DG is synthesize via gluconeogenesis taking amino acids as substrate. The glycogen decreasing in the DG at 120 min after feeding points out that used as an energy source for the digestive process. The glycogen concentration restoration in the DG 480 min post-feeding shows that this nutrient was again stored in preparation for the next digestive cycle.

\section{REFERENCES}

Aguado-Giménez, F., \& García-García, B. (2002). Growth and food intake models in Octopus vulgaris Cuvier (1797): influence of body weight, temperature, sex and diet. Aquaculture International, 10(5), 361-377.

Águila y Elvira, J. (2007). Bases nutricionales para el cultivo del pulpo Octopus maya (225 pp.) (tesis para obtener el grado de Maestría). Universidad Nacional Autónoma de México: México. 
Baesa-Rojano, E., Domingues, P., Capella, S., Noreña-Barroso, E., Caamal-Monsreal, C., \& Rosas, C. (2012). Marine gammarids (Crustacea: Amphipoda): a new live prey to culture Octopus maya hatchlings. Aquaculture Research, 44(10), 1602-1612. doi: 10.1111/j.1365-2109.2012.03169.x

Boucaud-Camou, E. (1968). Étude histologique et histochimique de l'appareil digestif de Sepiola atlantica d'Orbigny et Sepia officinalis L. Bulletin Society Linn Normandie, 9, 220-243.

Boucaud-Camou, E. (1973). Etude de l'appareil digestif de Sepia officinalis L. (Mollusque: Céphalopode). Essai d'analyse expérimentale des phénomènes digestifs (PhD Dissertation). University of Caen: France.

Boucaud-Camou, E., \& Boucher-Rodoni, R. (1983). Feeding and digestion in cephalopods. In A. S. M. Saleuddin \& K. M. Wilbur (Eds.). The Mollusca: New York: Academic Press

Boucher-Rodoni, R. (1976). Étude histologique du tube digestif de deux Cephalopodes Eledone cirrosa (Octopoda) et Illex illecebrosus (Teuthoidea), au cours de la digestion. Cahiers de Biologie Marine, 17, 254-260.

Boucher-Rodoni, R., Boucaud-Camou, E., \& Mangold, K. (1987). Feeding and digestion. In P. R. Boyle (Ed.), Cephalopod Life Cycles (vol. II). London: Academic Press

Budelmann, B. U., Schipp, R., \& Boletzky, S. (1997). Cephalopoda. In F. W. Harrison \& A. J. Kohn (Eds.), Microscopy anatomy of invertebrates (vol. 6A: Mollusca II). New York: Wiley-Liss.

Bustamante, P. (1998). Etude des processus de bioaccumulation et détoxification d'elements traces (métaux lourds et terres rares) chez les mollusques céphalopodes et bivalves pectinides. Implication de leur biodisponibilité pour le transfert vers les prédateurs (PhD Thesis). University of La Rochelle: France.

Cárdenas-López, J. L., \& Haard, N. F. (2005). Cysteine proteinase activity in jumbo squid (Dosidiscus jigas) hepatopacreas extracts. Journal of food biochemistry, 29(2), 171-186. doi: 10.1111/j.1745-4514.2005.00009.x

Cárdenas-López, J. L., \& Haard, N. F. (2009). Identification of a cysteine proteinase from Jumbo squid (Dosidicus gigas) hepatopancreas as cathepsin L. Food Chemistry, 112, 442-447.

Cerezo-Valverde, J., Martínez-Llorens, S., Vidal, A. T., Jover, M., Rodríguez, C., Estefanell, J., Gairín, J. I., Domingues, P., \& García-García, B. (2013). Amino acids composition and protein quality evaluation of marine species and meals for feed formulations in cephalopods. Aquaculture International, 21(2), 413-433.

D'Abramo, L. R. (1997). Triacylglycerols and Fatty Acids. In L. R. D'Abramo, D. E. Conklin \& D. M. Akiyama (Eds.). Crustacean Nutrition: Advances in World Aquaculture. Baton Rouge, Luisiana: World Aquaculture Society.

Estefanell, J., Roo, J., Guirao, R., Afonso, J. M., Fernández-Palacios, H., Izquierdo, M., \& Socorro, J. (2013). Efficient utilization of dietary lipids in Octopus vulgaris (Cuvier 1797) fed fresh and agglutinated moist diets based on aquaculture by-products and low price trash species. Aquaculture Research, 44(1), 93-105. doi: 10.1111/j.1365-2109.2011.03014.x
García-Garrido, S., Hachero-Cruzado, I., Domingues, P., López, N., \& Rosas, C. (2011). Effects of fish hydrolysate (CPSP $®)$ on growth and digestive gland lipid composition of Octopus vulgaris (Cuvier, 1797) juveniles. Aquaculture Nutrition, 17(4), e825-e839. doi: 10.1111/j.1365-2095.2010.00839.x

George-Zamora, A., Viana, M. T., Rodríguez, S., Espinoza, G., \& Rosas, C. (2011). Amino acid mobilization and growth of juvenile Octopus maya (Mollusca: Cephalopoda) under inanition and re-feeding. Aquaculture, 314(314), 215220. doi: 10.1016/j.aquaculture.2011.02.022

Hatfield, E. M. C., Rodhouse, P. G., \& Barber, D. L. (1992). Production of soma and gonad in maturing female Illex argentinus (Mollusca: Cephalopoda). Journal of the Marine Biological Association of United Kingdom, 72(2), 281-91. doi: $10.1017 / S 0025315400037693$

Hedstrom, L. (2002). Serine protease mechanism and specificity. Chemical Reviews, 102(12), 4501- 4524. doi: 10.1021/cr000033x

Herzberg, G. R., \& Lerner, J. (1973). The effect of preloaded amino acids on lysine and homoarginine transport in chicken small intestine. Comparative Biochemistry and Physiollogy Part A: Physiology, 44(1), 1-16. doi: 10.1016/0300-9629(73)90364-2

Linares, M., Rodríguez, S., Caamal-Monsreal, C., Olivares, A., Zúñiga, O., Sánchez, A., Pascual, C., Gallardo, P., \& Rosas, C. (2015). Timing of digestion, absorption and assimilation of octopus species living in tropical (Octopus maya) and sub-tropical-temperate (O. mimus) ecosystems. Aquatic Biology. In press

Lynch, M. P., \& Webb, K. L. (1973). Variations in serum constituents of the blue crab, Callinectes sapidus: free amino acids and total ninhydrin positive substances. Comparative Biochemistry and Physiollogy Part B: Comparative Biochemistry, 45(2), 407-418. doi: 10.1016/0305-0491(73)90074-6

Martínez, R., López-Ripoll, E., Avila-Poveda, O., Santos-Ricalde, R., Mascaró, M. \& Rosas, C. (2011a). Cytological ontogeny of the digestive gland in posthatching Octopus maya, and cytological background of digestion in juveniles. Aquatic Biology, 11, 249-261.

Martínez, R., Santos, R., Álvarez, A., Cuzón, G., Arena, L., Mascaró, M., Pascual, C., \& Rosas C. (2011b). Partial characterization of hepatopancreatic and extracellular digestive proteinases of wild and cultivated Octopus maya. Aquaculture International, 19(3), 445-457. doi: 10.1007/s10499-010-9360-5

Martínez, R., Santos, S., Mascaró, M., Canseco, L. Caamal-Monsreal, C., \& Rosas, C. (2012). Digestive dynamics during chyme formation of Octopus maya (Mollusca, Cephalopoda). Aquaculture Research, 43(8), 1119-1126. doi: 10.1111/j.1365-2109.2011.02915.x

Martínez, R., Gallardo, P., Pascual, C., Navarro, J., Sánchez, A., Caamal-Monsreal, C., \& Rosas, C. (2014). Growth, survival and physiological condition of Octopus maya when fed a successful formulated diet. Aquaculture, 426-427, 310-317. doi: 10.1016/j.aquaculture.2014.02.005

Miliou, H., Fintikaki, M., Kountouris, T., \& Verriopoulos, G. (2005). Combined ef fects of temperature and body weight on growth and protein utilization of the common octopus Octopus vulgaris. Aquaculture, 249(1-4), 245-256. doi: 10.1016/j.aquaculture.2005.03.038

Morishita, T. (1972). Studies on the distribution of proteolytic enzymes in the internal organs of Octopus. Bulletin of the Japanese Society of Scientific Fisheries, 38(8), 839-843. 
Mukhin, V. A., Smirnova, E. B., \& Novikov, V. Y. (2007). Peculiarities of Digestive Function of proteinases in invertebrates-inhabitants of cold seas. Journal of Evolutionary Biochemistry and Physiology, 43(5), 476-482.

Murray, R. K, Bender, D. A., Botham, K. M., Kennely, P. J., Rodwell, V. W., \& Weil, P. A. (2013). Bioquímica Harper. China: McGraw-Hill.

Pascual, C., Gaxiola, G., \& Rosas, C. (2003). Blood metabolites and hemocyanin of the white shrimp Litopenaeus vannamei: the effect of culture conditions and a comparison with other crustacean species. Marine Biology, 142(4), $735-745$.

Perrin, M. A. (2004). Etude expérimentale des capacités digestives chez la seiche, Sepia officinalis L. (Mollusque, Céphalopode): Impact de l'alimentation, indice de condition nutritionnelle et formulation d'un aliment artificiel (PhD. Thesis). University of Caen: Normandie.

Perrin, A., Le Bihan, E., \& Koueta, N. (2004). Experimental study of enriched frozen diet on digestive enzymes and growth of juvenile cuttlefish Sepia officinalis (Mollusca Cephalopoda). Journal Experimental Marine Biology and Ecology, 311(2), 267-285. doi: 10.1016/j.jembe.2004.05.012

Pérez, M. C., López, D. A., Águila, K., \& González, M. L. (2006). Feeding and growth in captivity of the octopus Enteroctopus megalocyathus. Aquaculture Research, 37(6), 550-555. doi: 10.1111/j.1365-2109.2006.01454.x

Prato, E., Portacci, G., \& Biandolino, F. (2010). Effect of diet on growth performance, feed efficiency and nutritional composition of Octopus vulgaris. Aquaculture, 309(1-4), 203-211. doi: 10.1016/j.aquaculture.2010.09.036

Rosa, R., Costa, P. R., \& Nunes, L. (2004). Effect of sexual maturation on the tissue biochemical composition of Octopus vulgaris and O. defilippi (Mollusca: Cephalopoda). Marine Biology, 145(3), 563-574.

Rosa. R., Costa, P. R., Bandarra, N., \& Nunes, M. L. (2005a). Changes in Tissue Biochemical Composition and Energy Reserves Associated With Sexual Maturation in the Ommastrephid Squids Illex coindetii and Todaropsis eblanae. The Biological Bulletin, 208(2), 100-113.

Rosa, R., Pereira, J., \& Nunes, M. L. (2005b). Biochemical composition of cephalopods with different life strategies, with special reference to a giant squid, Architeuthis sp. Marine Biology, 146(4), 739-751.

Rosas, C., Cooper, E. L., Pascual, C., Brito, R., Gelabert, R., Moreno, T., \& Sánchez, A. (2007). Physiological and immunological conditions of wild populations of Farfantepenaeus duorarum from the Campeche Sound (Crustacea Penaeidae). Marine Biology, 152(4), 929-938.
Rosas, C., Cuzon, G., Gaxiola, G., Pascual, C., Taboada, G., Arena, L., \& van Wormhoudt, A. (2002). An energetic and conceptual model of the physiological role of dietary carbohydrates and salinity on Litopenaeus vannamei juveniles. Journal of Experimental Marine Biology and Ecology, 268(1), 47-67. doi: 10.1016/S0022-0981(01)00370-7

Rosas, C., Sánchez, A., Pascual, C., Águila y Elvira, J., Maldonado, T., \& Domingues, P. (2011). Effects of two dietary protein levels on energy balance and digestive capacity of Octopus maya. Aquaculture International, 19(1), 165-180.

Rosas, C., Valero, A., Caamal-Monsreal, C., Uriarte, I., Farias, A., Gallardo, P., Sánchez, A., \& Domingues, P. (2013). Effects of dietary protein sources on growth, survival and digestive capacity of Octopus maya juveniles (Mollusca: Cephalopoda). Aquaculture Research, 44(7), 1029-1044. doi: 10.1111/j.1365-2109.2012.03107.x

Roura, A., González, A., Redd, K., \& Guerra, A. (2012). Molecular prey identification in wild Octopus vulgaris paralarvae. Marine Biology, 159(6), 1335-1345. doi: 10.1007/s00227-012-1914-9

Semmens, J. M. (2002). Changes in the digestive gland of the loliginid squid Sepioteuthis lessoniana (Lesson, 1830) associated with feeding. Journal of Experimental Marine Biology and Ecology, 274(1), 19-39.

Semmens, J. M., Doubleday, Z., Hoyle, K., \& Pecl, G. (2011). A multilevel approach to examining cephalopod growth using Octopus pallidus as a model. The Journal of Experimental Biology, 214, 2799-2807. doi: 10.1242/jeb.051631

Teshima, S. (1997). Phospholipids and Sterols. In L. D'Abramo, D. E. Conklin \& D. M. Akiyama (Eds.). Crustacean Nutrition, Advances in World Aquaculture. Baton Rouge, Louisiana: The World Aquaculture Society.

Undehim, E. A. B., Georgieva, D. N., Thoen, H. H., Norman, J. D., Mork, J., Betzel, C., \& Fry, B. G. (2010). Venom on ice: First insights into Antarctic octopus venoms. Toxicon, 56(6), 897-913. doi: 10.1016/j.toxicon.2010.06.013

Uriarte, I., Hernández, J., Dörner, J., Paschke, K., Farías, A., Crovetto, E., \& Rosas, C. (2010). Rearing and growth of the octopus Robsonella fontaniana (Cephalopoda: Octopodidae) from planktonic hatchlings to benthic juveniles. The Biologial Bulletin, 218, 200-210.

Zuñiga, O., Olivares, A., \& Ossandón, L. (1995). Influence of light in female sexual maturation of 0 . mimus. Estudios Oceanológicos, 14, 75-76. 